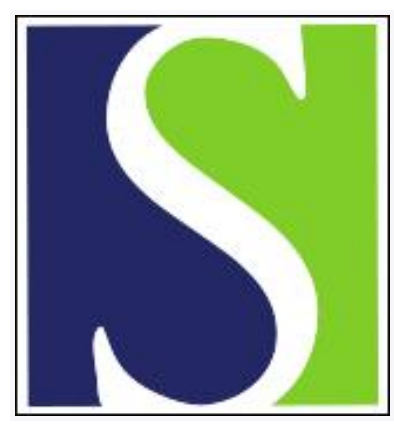

Scand J Work Environ Health 1991;17(1):32-37

https://doi.org/10.5271/sjweh.1737

Issue date: Feb 1991

Incidence of tenosynovitis or peritendinitis and epicondylitis in a meat-processing factory.

by Kurppa K, Viikari-Juntura E, Kuosma E, Huuskonen M, Kivi P

Affiliation: Institute of Occupational Health, Helsinki, Finland.

The following articles refer to this text: 2011;37(2):81-84;

2011;37(5):394-401

This article in PubMed: www.ncbi.nlm.nih.gov/pubmed/2047804 


\title{
Incidence of tenosynovitis or peritendinitis and epicondylitis in a meat-processing factory
}

\author{
by Kari Kurppa, MD, Eira Viikari-Juntura, MD, Eeva Kuosma, MSc, Matti Huuskonen, MD, MSc, \\ Pertti Kivi, MD ${ }^{1}$
}

\begin{abstract}
KURPPA K, VIIKARI-JUNTURA E, KUOSMA E, HUUSKONEN M, KIVI P. Incidence of tenosynovitis or peritendinitis and epicondylitis in a meat-processing factory. Scand $J$ Work Environ Health 1991;17:32-7. A 31-month follow-up study on the incidence of clinically ascertained tenosynovitis or peritendinitis in the hand and forearm regions and epicondylitis was conducted among 377 workers in strenuous manual jobs and 338 employees in manually nonstrenuous work in a large meat-processing factory. The clinical diagnosis of tenosynovitis or peritendinitis occurred 143 times and epicondylitis 68 times during the follow-up. The annual incidence of tenosynovitis or peritendinitis was less than $1 \%$ for employees in nonstrenuous jobs, $25.3 \%$ for female packers, $16.8 \%$ for female sausage makers, and $12.5 \%$ for male meatcutters. The annual incidence of epicondylitis was about $1 \%$ for employees in nonstrenuous jobs, $11.3 \%$ for female sausage makers, $7.0 \%$ for female packers, and $6.4 \%$ for male meatcutters. Workers typically resumed their jobs after returning from sick leave, and job transfers were rare.
\end{abstract}

Key terms: cold, follow-up study, job transfer, musculoskeletal, retirement, sick leave.

Awareness of soft-tissue diseases of the upper limbs has increased remarkably in the occupational health profession during recent years. In Australia "repetition strain injury," which is a term used to describe several soft-tissue conditions of the arm, has emerged as an epidemic (1). There has also been a dramatic increase in the number of claims for rheumatologic diseases in the United States (2). In Finland, compensation claims for tenosynovitis, peritendinitis, and epicondylitis have risen rapidly since changes towards more lenient criteria were implemented in insurance practice. Nowadays, the largest group of diseases in the Finnish Register of Occupational Diseases is made up of these illnesses (3).

Tenosynovitis, peritendinitis, and epicondylitis are soft-tissue diseases of the arm that are particularly troublesome to workers whose jobs demand dexterity and strenuous use of the hands $(4-10)$. Yet little systematic research has addressed various clinically important aspects of these diseases. There is also little information on how often such afflictions actually occur or how often job transfers are necessary.

The food and textile industries show the highest rates for cases of tenosynovitis, peritendinitis, and epicondylitis notified to the Finnish Register of Occupational Diseases (3). Therefore we chose one of the largest meat-processing factories of Western Europe for our epidemiologic study of these illnesses. The objectives of the study were to define the incidence rates of tenosynovitis, peritendinitis, and epicondylitis in speci-

\footnotetext{
${ }^{1}$ Institute of Occupational Health, Helsinki, Finland.
}

Reprint requests to: Dr K Kurppa, Department of Epidemiology and Biostatistics, Institute of Occupational Health, Topeliuksenkatu 41 a A, SF-00250 Finland. fied occupational categories, the typical duration of sick leaves, and the need for job transfers. The study was a part of a large investigation which gathered information on occurrences, cause-effect relations, and individual risk factors of selected upper-limb afflictions.

\section{Subjects and methods}

\section{Study population}

The study population was selected from among the workers of a large meat-processing company located in the Helsinki area. This particular company was chosen because its jobs were known to be stereotyped and strenuous to the arm, and a great number of illnesses among the workers had been notified to the Finnish Register of Occupational Diseases.

The cohort was cross-sectionally established on 1 October 1982, and its morbidity was followed until 30 April 1985. Workers whose tasks were strenuous to the muscle-tendon structures of the upper limbs and workers whose jobs did not contain such strain were included in the cohort. In the course of the follow-up new permanent workers were enrolled in the study after their completion of the company's mandatory three-month trial period.

All permanent workers in the meat-cutting, sausagemaking, and packing departments were included in the exposed (manually strenuous work) segment of the cohort. On 1 October 1982 the eligibility criteria were met by 311 workers employed in strenuous jobs. A fringe group of three female meatcutters was removed from the study. During the investigation, 69 new permanent employees entered the study in the strenuous job category. The exposed study population consist- 
ed therefore of 377 workers, that is, 102 male meatcutters, 18 male and 107 female sausage makers, and 32 male and 118 female packers.

On 1 October 1982, the company had 392 office workers, supervisors, and maintenance men whose work did not involve much strenuous manual exertion. Of them, 289 were selected to comprise an unexposed group comparable to the exposed one with regard to age, gender, and duration of employment. During the study period 49 new permanent workers were entered into the nonstrenuous job category. Thus the unexposed segment of the cohort consisted of $338 \mathrm{em}$ ployees (141 men and 197 women). Table 1 shows the occupational breakdown of the unexposed segment of the cohort.

On the whole, the age structure and seniority characteristics were reasonably similar for the main groups of workers employed in strenuous and nonstrenuous jobs (table 2). However, the small groups of male packers and male sausage makers were younger than the rest of the study population, and their length of employment was shorter.

\section{Health care arrangements}

The company had an occupational health care unit and four full-time occupational health nurses. The health care unit was visited each workday by one of the two part-time plant physicians, both of whom were specialists in occupational health. Medical care was free of charge, including the services of consulting surgeons, orthopedic surgeons, physiatrists, and neurologists at a nearby private medical center where the workers were usually treated if they visited physicians other than company doctors. The preplacement medical examinations did not preclude applicants with a history of musculoskeletal disease.

Sick-leave certificates and records were kept by the occupational health unit of the company. If the employees sought medical advice outside the company's occupational health unit (typically during summer vacations, weekends) the medical bills were reimbursed by the company nurses, who recorded the causes of such visits and filed the sick-leave certificates.

\section{Case definition}

Before the study, the diagnostic criteria were agreed upon with the plant physicians, who treated the majority of the workers.

The criteria for tenosynovitis or peritendinitis in the hand and forearm regions were swelling or crepitation and tenderness to palpation along the tendon and pain at the tendon sheath, in the peritendinous area, or at the muscle-tendon junction during active movement of the tendon. Tenosynovitis and peritendinitis were combined into one category because these diagnoses are often interchangeably used by physicians. The affliction called “de Quervain's disease” (meaning a stenosing tenosynovitis of the tendon sheaths of the long abductor and short extensor muscles of the thumb) was also included in this category if no signs of stenosing tenosynovitis, such as a positive Finkelstein's test, were noted in the medical files.

The criteria for lateral or medial epicondylitis were tenderness to palpation of the epicondyle and epicondylar pain provoked by resisted extension or flexion of the wrist and fingers with the elbow extended.

Of the diagnoses of tenosynovitis or peritendinitis and epicondylitis, $75 \%$ were made by the company doctors, $13 \%$ by consulting specialists at the nearby medical center, and $12 \%$ elsewhere, usually at municipal health centers.

\section{Incidence rates}

The disease was considered one episode if a new sick leave with the same diagnosis occurred at the same anatomic site within $60 \mathrm{~d}$ after the end of a former sick leave. Otherwise recurrence was considered as another episode, even if the site of the disease was the same.

For the incidence density calculations, time-at-risk was accumulated for each individual since entry into the cohort until the day of diagnosis, change of department, termination of employment, or end of followup. If a packer, for instance, changed jobs and was employed as a maker of sausages, he or she contributed time-at-risk first to the former and then to the latter

Table 1. Occupational breakdown of the workers in manually nonstrenuous jobs by gender.

\begin{tabular}{lcc}
\hline Job description & Men & Women \\
\hline Supervisors, executives & 74 & 16 \\
Maintenance men & 31 & - \\
Sales persons & 17 & 20 \\
Keyboard operators & 1 & 28 \\
Accountants & -1 & 49 \\
Typists, clerks & 17 & 40 \\
Others & 141 & 44 \\
\hline Total & & 197 \\
\hline
\end{tabular}

Table 2. Age and years of employment of the workers in the different occupational groups at the time of entry into the study.

\begin{tabular}{|c|c|c|c|c|}
\hline \multirow[t]{2}{*}{$\begin{array}{l}\text { Occupational } \\
\text { group }\end{array}$} & \multicolumn{2}{|c|}{ Age (years) } & \multicolumn{2}{|c|}{$\begin{array}{l}\text { Length of employ- } \\
\text { ment in present task } \\
\text { (years) }\end{array}$} \\
\hline & Median & Range & Median & Range \\
\hline \multicolumn{5}{|l|}{ Meatcutters } \\
\hline Men $(N=102)$ & 37 & $23-56$ & 12.0 & $2.0-33$ \\
\hline \multicolumn{5}{|l|}{ Sausage makers } \\
\hline $\begin{array}{l}\text { Men }(N=18) \\
\text { Women }(N=107)\end{array}$ & $\begin{array}{l}24 \\
38\end{array}$ & $\begin{array}{l}18-35 \\
18-61\end{array}$ & $\begin{array}{l}2.0 \\
9.1\end{array}$ & $\begin{array}{l}0.3-12 \\
0.3-32\end{array}$ \\
\hline \multicolumn{5}{|l|}{ Packers } \\
\hline $\begin{array}{l}\text { Men }(N=32) \\
\text { Women }(N=118)\end{array}$ & $\begin{array}{l}21 \\
34\end{array}$ & $\begin{array}{l}17-46 \\
17-57\end{array}$ & $\begin{array}{l}0.5 \\
3.2\end{array}$ & $\begin{array}{l}0.3-6 \\
0.3-18\end{array}$ \\
\hline \multicolumn{5}{|l|}{$\begin{array}{l}\text { Workers in } \\
\text { nonstrenuous jobs }\end{array}$} \\
\hline $\begin{array}{l}\text { Men }(N=141) \\
\text { Women }(N=197)\end{array}$ & $\begin{array}{l}37 \\
36\end{array}$ & $\begin{array}{l}19-63 \\
17-64\end{array}$ & $\begin{array}{l}6.8 \\
5.8\end{array}$ & $\begin{array}{l}0.3-25 \\
0.3-30\end{array}$ \\
\hline
\end{tabular}


job category. A worker was considered "cured" and a candidate for a new similar affliction $60 \mathrm{~d}$ after the termination of sick leave.

The groups of male packers and male sausage makers were too small for the calculation of reliable incidence rates. These groups were included in the total figures of the male workers in strenuous jobs however.

We calculated the incidence rates by using a personyears Fortran program for cohort study analyses (11). The confidence limits for the rate ratio point estimates were calculated according to the method of Miettinen \& Nurminen (12).

\section{Job transfers and termination of employment}

The occupational health nurses and supervisors checked the reasons for the job transfers and employment terminations of the permanent workers between 1 October 1982 and 30 April 1984. The persons who left the company were also sent a questionnaire on the occurrence of disorders and symptoms of the upper limbs. The questionnaire response rates were $78 \%$ for the workers from strenuous jobs and $85 \%$ for those from nonstrenuous jobs.

\section{Results}

\section{Tenosynovitis and peritendinitis}

Tenosynovitis or peritendinitis appeared 143 times among 104 workers. Of the diagnoses 137 were made among 98 workers in strenuous jobs. The disease was diagnosed in only six workers with nonstrenuous jobs. The afflicted workers in strenuous and nonstrenuous jobs did not differ with respect to age or seniority characteristics or the duration of sick leave. The median age of the affected individuals was 36 (range

Table 3. Number of afflictions and the incidence density of tenosynovitis or peritendinitis and epicondylitis by occupational group.

\begin{tabular}{|c|c|c|c|c|}
\hline \multirow[b]{2}{*}{ Job category } & \multicolumn{2}{|c|}{$\begin{array}{l}\text { Tenosynovitis or } \\
\text { peritendinitis }\end{array}$} & \multicolumn{2}{|c|}{ Epicondylitis } \\
\hline & $\begin{array}{l}\text { Number } \\
\text { of cases }\end{array}$ & $\begin{array}{c}\text { Rate per } \\
100 \text { person- } \\
\text { years }\end{array}$ & $\begin{array}{l}\text { Number } \\
\text { of cases }\end{array}$ & $\begin{array}{c}\text { Rate per } \\
100 \text { person- } \\
\text { years }\end{array}$ \\
\hline \multicolumn{5}{|l|}{ Meatcutters } \\
\hline Men & 31 & 12.5 & 16 & 6.4 \\
\hline \multicolumn{5}{|c|}{ Sausage makers } \\
\hline Women & 37 & 16.8 & 25 & 11.3 \\
\hline \multicolumn{5}{|l|}{ Packers } \\
\hline Women & 64 & $25.3^{a}$ & 18 & 7.0 \\
\hline \multicolumn{5}{|l|}{ Total } \\
\hline \multicolumn{5}{|c|}{ Strenuous jobs } \\
\hline $\begin{array}{l}\text { Menb } \\
\text { Women }\end{array}$ & $\begin{array}{r}36 \\
101\end{array}$ & $\begin{array}{l}11.0 \\
21.4\end{array}$ & $\begin{array}{l}17 \\
43\end{array}$ & $\begin{array}{l}5.2 \\
8.9\end{array}$ \\
\hline \multicolumn{5}{|c|}{ Nonstrenuous jobs } \\
\hline $\begin{array}{l}\text { Men } \\
\text { Women }\end{array}$ & $\begin{array}{l}3 \\
3\end{array}$ & $\begin{array}{l}0.9 \\
0.7\end{array}$ & $\begin{array}{l}3 \\
5\end{array}$ & $\begin{array}{l}0.9 \\
1.1\end{array}$ \\
\hline
\end{tabular}

a Rate ratio and $95 \%$ confidence interval for female packers versus female sausage makers: 1.5 and $1.0-2.2$, respectively.

Including male packers and sausage makers.
17-58, the 10th percentile 23) years, and the median length of employment was 9 (range $0.3-21$ ) years. The duration of sick leave had a median of 10 (range $0-79$, the 90 th percentile 22) $\mathrm{d}$.

The dominant hand was affected in $72 \%$ of the cases. Eight workers received a diagnosis of de Quervain's disease. But none of them had clinical signs consonant with stenosing tenosynovitis, and the clinical course of the disease was similar to that of other spells of the tenosynovitis and peritendinitis category. No worker was operated on because of tenosynovitis or peritendinitis.

\section{Epicondylitis}

There were 68 diagnoses of epicondylitis among 57 individuals. The disease appeared overwhelmingly among the workers in the strenuous jobs - there were only eight cases among six workers in nonstrenuous jobs. The age and seniority characteristics and the duration of the sick leaves were similar both for the afflicted workers in strenuous and nonstrenuous jobs and for the men and women. The median age of the afflicted workers was 41 (range 19-56, the 10th percentile 28) years. The median length of employment of the afflicted workers was 10 (range $0.3-32$ ) years. The duration of the sick leave had a median of 16 (range $0-109$, the 90 th percentile 70 ) d.

The right elbow was affected in $80 \%$ of the afflicted men and in $67 \%$ of the afflicted women. The lateral epicondylar region was the site affected in $60 \%$ of the afflicted men, and in $89 \%$ of the women. During the follow-up, one employee in a nonstrenuous job was operated on because of epicondylitis.

Four female workers (one packer, three sausage makers) had lateral epicondylitis simultaneously in both elbows. In addition, one female packer had epicondylitis in the lateral and medial epicondyles of both elbows simultaneously; she was on sick leave for $26 \mathrm{~d}$ and had no further afflictions during the rest of the 10.5 months of follow-up.

\section{Incidence rates}

The employees from nonstrenuous jobs rarely sought medical advice for tenosynovitis or peritendinitis or epicondylitis - about one case per 100 workers was recorded per year (table 3 ). In contrast, such afflictions were frequent causes of medical consultations among the workers in strenuous jobs. The unadjusted incidence of tenosynovitis or peritendinitis of the female packers was statistically higher than that of the female sausage makers.

\section{Job transfers}

Job transfers were rare, only 14 individuals changed departments between 1 October 1982 and 30 April 1984. Five packers moved to nonstrenuous jobs (one had had tenosynovitis and another tenosynovitis and 
epicondylitis), and four packers transferred to the sausage-making department. Four sausage makers moved to nonstrenuous jobs (one had a history of epicondylitis twice within a year), and one sausage maker transferred to the packing department. None of the meatcutters changed departments.

\section{Job termination}

Twenty-seven workers in strenuous jobs and 33 in nonstrenuous jobs left the company. Finding a better job elsewhere, continuation of studies, change of place of residence, and unemployment pension made up the majority $(55 \%)$ of the reasons. There were no marked differences in the reasons for leaving between the workers in strenuous or nonstrenuous jobs. Two workers in strenuous work and three in nonstrenuous work reported that the job termination was due to illness. One sausage maker resigned because of four spells of carpal tenosynovitis within a year. He was the only one that we found who terminated his job because of an upper-limb illness.

\section{Discussion}

We calculated the incidence density estimates by including all separate spells of the disease that occurred in the dynamic study population instead of using cumulative incidence estimates based on first occurrences only. (The criterion for a new spell was a minimum interval of $60 \mathrm{~d}$ between the end and the start of the spells.) There is room for discussion whether some of the separate episodes were indeed recurrences of the same disease. However, the interval between episodes typically was fairly long. Thirty-nine employees repeatedly afflicted by tenosynovitis or peritendinitis had a median interval of $233 \mathrm{~d}$ between episodes; the lower quartile was $160 \mathrm{~d}$. Twelve employees afflicted by epicondylitis had another spell with the median interval of $184 \mathrm{~d}$ between the spells; the lower quartile was $123 \mathrm{~d}$. Furthermore, we consider it unlikely that many individuals with clinical epicondylitis, tenosynovitis, or peritendinitis could last several weeks in the strenuous jobs that were typical to our patients without seeking medical advice.

The results indicated that clinically ascertained morbidity due to tenosynovitis or peritendinitis was low among the employees in manually nonstrenuous jobs, the incidence being less than one per 100 person-years. Results from a Finnish cohort of 7600 workers from diverse trades has previously indicated an incidence rate of 0.4 cases per 100 person-years (13). Among 12000 English car-factory workers in the $1940 \mathrm{~s}, 0.3 \%$ contracted tenosynovitis or peritendinitis annually (14). Our rates were based on a few cases only (three afflictions among the men, three among the women), and therefore the estimates are inaccurate. On the other hand, the recording of the afflictions in our closely fol- lowed cohort may have been more comprehensive than that of the reported studies of much larger populations.

Contrary to the low rates of occurrence among the workers in nonstrenuous jobs, we found the clinically ascertained morbidity of tenosynovitis or peritendinitis conspicuously high in jobs characterized by strenuous use of the hands. A morbidity of the same order of magnitude has been reported among 700 Muscovite tea packers in the 1920 s when 189 cases ( 244 visits to the health care unit) were detected within eight months (15); these figures would translate to 41 cases per 100 workers per year.

The diagnosis of de Quervain's disease is sometimes used by physicians for simple tenosynovitis near the radial styloid process in the carpal region. No case fulfilling the criteria of de Quervain's disease was detected in our study, and none of our patients had to be operated on. Obolenskaja \& Goljanitzki (15) described the development of stenosing tendovaginitis in many workers who had a long history as tea packers. An English report which included 125 cases of tenosynovitis reported two cases of de Quervain's disease (14). Kivi (13) reported that two out of 86 Finnish patients that needed an operation had stenosing tenosynovitis.

A two-year follow-up of 5000 German workers in the 1960s showed an epicondylitis incidence of $1.5 \%$ per year (16). Allander (17) estimated the annual incidence of epicondylitis in a Swedish population to be less than $1 \%$. A two-year follow-up of epicondylitis morbidity among 7600 Finnish workers from different trades showed results which would correspond to an incidence of 0.6 cases per 100 person-years (18). These incidence figures approximate those detected among the workers in nonstrenuous jobs ( 0.9 for the men, 0.7 for the women) in our study, while our incidence rates were many times higher for workers in manually strenuous jobs.

The average sick leave for a patient with epicondylitis has been reported to be $14.4 \mathrm{~d}$, and the average duration of the disease $216 \mathrm{~d}$ (18). In our study the median length of the sick leave was $16 \mathrm{~d}$. According to the plant physicians the workers usually still had pain on palpation at the epicondyle when returning to work, but the provocation test was negative. Only one worker (nonstrenuous job) out of our 56 individuals with epicondylitis had to be operated on. This rate corresponds to the experience of Kivi (18), who noted that two patients out of 80 had to be operated on. Others have reported that $3-11 \%$ of the patients with epicondylitis need an operation $(19,20)$.

It may be worth noting that in our study the clinically ascertained morbidity was low among the $117 \mathrm{fe}$ male office employees whose work involved keyboard work (keyboard operators, accountants, typists). During the follow-up only two of them sought medical attention because of tenosynovitis or peritendinitis, and three of them because of epicondylitis.

It is improbable that the low morbidity of clinically ascertained diseases among the employees in non- 
strenuous jobs was due to such incidents not having been recorded. The employees who sought medical advice outside the company's health care unit were reimbursed for the costs when the bills were presented to the company's nurses, who consequently also recorded the diagnoses of these events. There is, however, another mechanism which probably led to a strong underreporting of the episodes among the employees in nonstrenuous jobs. The extent to which a person affected is occupationally disadvantaged depends on the demands of the job. For instance, epicondylitis of a similar clinical severity may mean "total" vocational handicap to a meatcutter but little discomfort to a foreman. The meatcutter must seek medical attention, while the foreman often may just wait for the symptoms to disappear. It is very possible that most of the afflictions of workers in nonstrenuous jobs remain unknown to the medical personnel, the result being a gross incomparability of true morbidity between different occupations. Therefore, the comparison of incidence rates between the employees in strenuous versus nonstrenuous jobs is liable to considerable bias, the extent of which is difficult to estimate in a followup study of clinically ascertained episodes.

Although 211 clinically ascertained episodes of tenosynovitis or peritendinitis or of epicondylitis occurred during the follow-up, job transfers due to upper-limb illnesses were initiated in only three instances. In addition, one packer and two sausage makers were moved to a less strenuous job because of aching wrists or forearms although they did not show a manifest form of illness. These facts support our general impression that the diseases under study generally followed a mild course.

According to clinical experience the disease of some individuals may first be manifest as epicondylitis, tenosynovitis, or peritendinitis and remain resistent to all efforts of treatment, either continuing at the same anatomic location or changing site and type but still affecting the soft-tissue structures of the arms. Efforts to find a systemic disease, such as rheumatoid arthritis, which could explain the atypical course of the disease often remain unsuccessful. Although we have seen such patients, the present study detected few intractable cases. Therefore, we think that such afflictions are relatively rare, although they may aggregate in the offices of hand surgeons.

The unadjusted incidence of tenosynovitis/peritendinitis among the female packers was statistically higher than that of female sausage makers of the same age. The most notable difference between the work conditions of these groups was the ambient temperature. The packers worked in a temperature of $8-10^{\circ} \mathrm{C}$, whereas the temperature in the sausage makers' workroom was $20^{\circ} \mathrm{C}(21)$.

The workers who started employment during the course of the follow-up formed a particularly interesting subgroup because of impressions, thus far largely anecdotal, which have linked new workers to a par- ticularly high risk with regard to soft-tissue morbidity of the arm. The analyses of the present data will continue through the modeling of the risks of morbidity with the use of multivariate methods and a number of potentially important variables.

\section{Acknowledgments}

We are indebted to the Finnish Farmers' Meat Central for its valuable help throughout this study. We also wish to extend our appreciation to the workers who participated in this study, to Dr M Partinen for his contribution to the early phases of the study, to Dr H Riihimäki for her useful comments during the writing of the report, and to the Finnish Work Environment Fund for its financial support.

\section{References}

1. McDermott FT. Repetition strain injury: a review of current understanding. Med J Aust 1986;144:196-200.

2. Morse LH. Repetitive motion musculoskeletal problems in the microelectronics industry. In: La Dou J, ed. The microelectronics industry. Philadelphia, PA: Hanley \& Belfus Inc, 1986:167-74. (Occupational medicine: state of the art reviews; no 1).

3. Vaaranen V, Vasama M, Toikkanen J. Occupational diseases in Finland in 1989. Helsinki: Institute of Occupational Health, 1990.

4. Hadler NM. Industrial rheumatology. Arthritis Rheum 1977;20:1019-24.

5. Kurppa K, Waris P, Rokkanen P. Peritendinitis and tenosynovitis: a review. Scand J Work Environ Health 1979;5(suppl 3):19-24.

6. Kurppa K, Waris P, Rokkanen P. Tennis elbow: lateral elbow pain syndrome. Scand J Work Environ Health 1979;5(suppl 3):15-8.

7. Viikari-Juntura E. Tenosynovitis, peritendinitis and the tennis elbow syndrome. Scand J Work Environ Health 1984;10:443-9.

8. Punnett L, Robins JM, Wegman DH, Keyserling WM. Soft tissue disorders in the upper limbs of female garment workers. Scand J Work Environ Health 1985;11: 417-25.

9. Armstrong TJ, Silverstein BA. Upper-extremity pain in the workplace - role of usage in causality. In: Hadler $\mathrm{N}$, ed. Clinical concepts in regional musculoskeletal illness. Orlando, FL: Grune \& Stratton, 1987:333-54.

10. Thompson D, Rawlings AJ, Harrington JM. Repetition strain injuries. In: Harrington JM, ed. Recent advances in occupational health. Edingburgh: Churchill Livingstone, 1987:75-89.

11. Coleman MP, Hermon C, Douglas A: Person-years (PYRS): a Fortran program for cohort study analysis. Lyon: International Agency for Research on Cancer, 1989:1-61.

12. Miettinen OS, Nurminen M. Comparative analysis of two rates. Stat Med 1985;4:213-26.

13. Kivi $P$. Käden ja kyynärvarren rasitusperäinen tenosynoviitti ja peritendiniitti [Occupational tenosynovitis and peritendinitis of the arm and hand]. Duodecim 1981;97:729-36. (English summary.)

14. Thompson AR, Plewes LW, Shaw EG. Peritendinitis crepitans and simple tenosynovitis: a clinical study of 544 cases in industry. $\mathrm{Br} \mathrm{J}$ Ind Med 1951;8:150- 60 .

15. Obolenskaja AJ, Goljanitzki JA. Die seröse Tendovaginitis in der Klinik und im Experiment. Dtsch Z Chir 1927;201:388-99. 
16. Manz A, Rausch W. Zur Pathogenese und Begutachtung der Epicondylitis humeri. Münch Med Wochenschr 1965;29:1406-13.

17. Allander E. Prevalence, incidence and remission rates of some common rheumatic diseases and syndromes. Scand J Rheumatol 1974;3:145-53.

18. Kivi $P$. The etiology and conservative treatment of humeral epicondylitis. Scand J Rehabil Med 1983;15: $37-41$.

19. Boyd H, McLeod A. Tennis elbow. J Bone Joint Surg 1973;55-A:1183-7.
20. Coonrad RW, Hooper WR. Tennis elbow: its course, natural history, conservative and surgical management. J Bone Joint Surg 1973;55-A:1177-82.

21. Viikari-Juntura E, Kurppa K, Kuosma E, Huuskonen M, Kuorinka I, Ketola R, Könni U. Prevalence of epicondylitis and elbow pain in the meat-processing industry. Scand J Work Environ Health 1991;17:38-45.

Received for publication: 4 May 1990 